\title{
Aikuiskasvatuksen tutkimusseminaari
}

Tämän lehden sisältö on koottu Tampereen Varalassa 19.-21.8. pidetyn aikuiskasvatustutkimuksen nykytilaa ja kehittämistarpeita käsittelevän seminaarin aineistosta.

Aloitteen seminaarin järjestämisestä teki opetusministeriö kehottaen keväällä 1985 aikuiskoulutusneuvostoa esittämään sitä koskevia näkökohtia. Neuvosto ehdotti syksyllä 1985, että opetusministeriö järjestäisi "'aikuiskoulutustutkimusta koskevan teemaseminaarin, jonka tavoitteena olisi virittää kiinnostus alan tutkimusta kohtaan sekä tuoda esiin tärkeitä tutkimuskohteita'’. Opetusministeriö päätti tammikuussa 1986 antaa seminaarin valmistelun ja järjestämisen Tampereen yliopiston tehtäväksi kutsuen valmistelutyötä johtamaan professori Aulis Alasen. Edustajikseen valmisteluryhmään ministeriö nimesi korkeakouluneuvos Anneli Mäkisen ja apulaisosastopäällikkö Olavi Alkion. Suunnittelun alettua valmistelutyöryhmään kutsuttiin lisäksi professori Seppo Kontiainen Helsingin yliopistosta ja apulaisprofessori Tapio Vaherva Jyväskylän yliopistosta. Käytännön järjestelyistä huolehti Tampereen yliopiston täydennyskoulutuskeskus ja sen edustajana oli työryhmässä koulutussuunnittelija Hilkka Raittila.

Opetusministeriön edustajat pitivät tärkeänä, että seminaari olisi niin ohjelmaltaan kuin osallistujien osalta laaja-alainen; tarkoituksena oli eräänlaisen tietoiskun tapaan kiinnittää yliopistoväen, valtionhallinnon ja käytännön edustajien huomiota aikuiskasvatustutkimukseen ja toisaalta saada esille odotuksia ja ideoita tutkimuksen suuntaamisesta.

Yli sadan henkilön osallistujamäärä oli odotettua suurempi. Kun organisaatioille osoitettu kutsumis- ja kiintiömenettely ei - mm. virkamieslakon vuoksi - täysin toiminut, osallistujajoukko ei jakautunut niin tasasuhtaisesti kuin oli toivottu. Yliopistotutkijain osuus jäi vähäiseksi ja käytännön edustajista elinkeinoelämän henkilöstökoulutuksen organisaatiot olivat aliedustuneita.

Järjestäjien näkökulmasta seminaari kokonaisuutena täytti kuitenkin käsittääkseni kohtuulliset odotukset. Alustajiksi onnistuttiin saamaan varsin hyvin ne asiantuntijat, joita tavoitettiinkin. Erityisen arvokasta oli että kansainvälisiä näkymiä saatiin valottamaan kaksi alansa johtavaa tutkijaa, professorit Horst Siebert ja Kjell Rubenson. Sain sen vaikutelman että näiden esityksiin oltiin myös varauksettomimmin tyytyväisiä. Psykologisen tutkimuksen esittely jäi yhteensattumien vuoksi ohjelmasta ja kahden sairaustapauksen takia jouduttiin jaostoalustuksiin tekemään vastaavat henkilömuutokset. Keskustelu, jota varten aikaa olisi tietysti saanut olla enemmän, oli aktiivista ja asiapitoista. Konkreettisia tutkimusideoita ja kehittämisehdotuksia ei kolmantena päivänä ehkä tullut aivan odotetulla tavalla.

Valmistelevan työryhmän ajatuksena oli että Varalan seminaari olisi yleiskatsauksellinen avaus jatkuvalle, määrävälein toistuvien tutkimusseminaarien sarjalle. Tässä tarkoituksessa osallistujia pyydettiin täyttämään lomake, jossa tiedusteltiin uusia seminaareja koskevia odotuksia ja ideoita. Kuten tavallista lomakkeen täytti vain pieni osa osallistujista (22). Vastaajat pitivät seminaarien järjestämistä "'erittäin tarpeellisena"' ja tarkemmat ehdotukset olivat samansuuntaisia kuin valmisteluryhmänkin kaavailut: seminaarit tulisi eriyttää esimerkiksi tutkijain keskinäisiin tapaamisiin, tutkijain ja hallinnon yhteistilaisuuksiin sekä Varalan seminaarin tapaisiin mutta kohderyhmää jäsentäen ja osallistujamäärää supistaen.

Opetusministeriöllä on Varalan kokemusten perusteella mitä ilmeisin tilaus jatkaa aikuiskasvatustutkimuksen seminaarien järjestämistä yhteistyössä niiden yliopistojen kanssa, joissa aikuiskasvatus on oppiaineena. 


\section{Aikuiskasvatuksen tutkimusseminaarin ohjelma}

Teema: $\quad$ Aikuiskasvatustutkimuksen nykytila ja kehitystarpeet

Yleistavoite: Koota ja välittää tietoa aikuiskasvatuksen ja sen edellytyksiin kohdistuvan tutkimuksen nykytilasta, inventoida tutkimustarpeita ja -resursseja sekä virittää kiinnostusta alan tutkimusta kohtaan.

\section{Tiistai 19.8. KANSAINVÄLISIÄ NÄKÖALOJA}

13.00-13.15 Tampereen yliopiston tervehdys

13.30-15.00 Aikuiskasvatuksen tutkimus kehittyneissä koulutusyhteiskunnissa

15.30-17.00 Eurooppalainen aikuiskasvatustutkimus länsisaksalaisesta näkökulmasta

18.00-18.30 Aikuiskasvatuksen tutkimustoiminta neljässä Pohjoismaassa ja Saksan liittotasavallassa

18.30-20.00 Keskustelua ulkomaisten asiantuntijoiden kanssa vararehtori Viljo Rasila

professori Kjell Rubenson 1$)$

professori Horst Siebert

KT Eero Pantzar

Keskiviikko 20.8. TUTKIMUKSEN NYKYTILA SUOMESSA

9.30-10.00 Avauspuheenvuoro

10.00-12.00 Suomen aikuiskasvatustutkimuksen nykynäkymiä

13.00-13.40 Aikuisdidaktinen tutkimus

13.50-14.30 Aikuiskasvatuksen sosiologinen tutkimus

15.00-17.00 Jaostotyöskentelyä

Jaosto A. Työelämän koulutus

Jaosto B. Aikuisten opintoaktiviisuus

18.00-19.30 Tutkimuskäräjät. Kantajina tutkimuksen käyttäjät, vastaajina tutkijat.

Yleistä keskustelua. opetusministeri Pirjo Ala-Kapee

professori Aulis Alanen

FT Ritva Jakku-Sihvonen apul.prof. Tapio Vaherva

FL Urpo Sarala ja

FL Jukka Tuomisto

YK Raimo Jaakkola dosentti Terttu Gröhn ${ }^{2}$ )

\section{Torstai 21.8. TUTKIMUSTARPEET JA -MAHDOLLISUUDET}

9.00-9.30 Tutkimus osana valtakunnallista kehittämistyötä

Aikuiskoulutusneuvoston pj. FT Tytti Isohookana-Asunmaa

9.30-12.00 Mitä kenttä odottaa tutkimukselta?

13.00-15.00 Hallinnon ja käytännön edustajien puheenvuoroja. Tutkimuksen edustajien kommentteja. Keskustelua.

Seminaarin päättäminen

1) Kjell Rubensonin alustus julkaistaan myöhemmin.

2) Terttu Gröhnin alustus korkeakouluopiskelijoiden käsityksistä on julkaistu Helsingin yliopiston kasvatustieteen laitoksen sarjassa Tutkimuksia 107, Seppo Kontiainen (toim.) Näkökulmia aikuiskoulutuksen tutkimukseen. 